\title{
Considerações acerca do campo religioso atual: diálogo ecumênico e inter-religioso
}

\author{
Fabricio Veliq*
}

\section{Resumo}

O presente artigo tem o intuito de abordar as temáticas do diálogo ecumênico e do diálogo inter-religioso no campo religioso atual, apresentando perspectivas teológicas para a compreensão dessas duas abordagens. Para o diálogo ecumênico, apresentamos um panorama histórico de sua evolução, a fim de entendermos os avanços e identificarmos algumas lacunas que ainda se mostram na atualidade cristã. Para o diálogo inter-religioso, focamos em trabalhar a temática da pluralidade religiosa presente no mundo atual como fruto da Modernidade e apresentar importantes apontamentos de diversos teólogos do século XX.

Palavras-chave: Atualidade; Diálogo; Diálogo inter-religioso; Ecumenismo; Pluralismo religioso.

\section{Considerations about the current religious field: Ecumenical and inter-religious dialogue}

\begin{abstract}
This article aims to approach two themes in the current religious scenario: the Ecumenical dialog and inter-religious dialogue, introducing some perspectives for comprehension about these two topics. In related to Ecumenical dialogue, we present a historical overview of his evolution, to try to understand the advances and to identify some lacks that remains nowadays about this subject. In related to the inter-religious dialogue, our focus is the religious plurality existent in our world as consequence of the Modernity and in showing some important considerations from $21^{\text {st }}$ century theologians Key-words: Actuality; Dialog; Inter-religious dialog; Ecumenism; Religious plurality.
\end{abstract}

\footnotetext{
* Faculdade Jesuíta de Filosofia e Teologia de Belo Horizonte. Katholieke Universiteit Leuven. Doutor em Teologia pela Faculdade Jesuíta de Filosofia e Teologia. Doctor in Theology pela Katholieke Universiteit Leuven. Email: fveliq@gmail.com
} 


\section{Consideraiciones acerca del campo religioso actual: diálogo ecumênico e interreligioso}

\section{Resumen}

El presente artículo tiene el propósito de abordar las temáticas del diálogo ecuménico y del diálogo interreligioso en el campo religioso actual, presentando perspectivas teológicas para la comprensión de estos dos enfoques. Para el diálogo ecuménico, presentamos un panorama histórico de su evolución, a fin de entender los avances e identificar algunas lagunas que aún se muestran en la actualidad cristiana. Para el diálogo interreligioso, enfocamos en trabajar la temática de la pluralidad religiosa presente en el mundo actual como fruto de la Modernidad y presentar importantes apuntes de diversos teólogos del siglo XX.

Palabras-clave: Actualidad; Diálogo; Diálogo interreligioso; Ecumenismo; Pluralismo religioso

\section{Introdução}

Falar sobre o campo religioso atual se mostra como uma tarefa extremamente desafiadora. Atualmente, passa-se por um tempo de inúmeras incertezas econômicas, políticas e sociais tanto em nosso país quanto ao redor do mundo (LEVY, 2019, p.1). São diversas as notícias de ameaças de guerras armadas e nucleares, milhões de pessoas em situação de risco, fugindo de sistemas totalitários e fortes extremismos religiosos.

Por outro lado, vê-se surgir uma onda reacionária, também ancorada em outro tipo de extremismo religioso, do tipo cristão. Esse movimento, que se assemelha muito àqueles que fizeram subir ao poder figuras como Hitler e Mussolini, se mostra crescente em países França e Inglaterra. Recentemente, a Suíça, constantemente conhecida pela sua neutralidade, se viu em um processo eleitoral que levou ao poder um membro da extrema-direita do país (Jornal Estadão de 18/10/2015).

Em solo norte-americano, por sua vez, vê-se a figura de Donald Trump como novo presidente dos Estados Unidos da América. Seu discurso populista de fazer a América grande novamente conseguiu encantar diversas pessoas, principalmente aquelas que, devido ao sistema capitalista neoliberal que gera competitividade desonesta em todos os setores da sociedade, perderam seus empregos e se viam em situação de pobreza e necessidades (Deustch Welle de 18/07/2016).

No Brasil, após o impeachment da presidenta Dilma Roussef, o país mergulha em uma crise ainda maior, tendo no último ano, aumentado o número de desempregados para mais de catorze milhões de brasileiros e 
brasileiras (PNAD Contínua IBGE 2017; Site UOL de 28/04/2017). Diante desse cenário, também se vê crescer, devido à desesperança de muitos, bem como ao oportunismo de vários, movimentos de extrema direita, que pregam a segregação e a intolerância com grupos minoritários, como o movimento LGBT'T'T, os negros, os pobres e os indígenas. O ataque a essas minorias se justifica, aos olhos dos extremistas, como solução para os problemas do país e, não dificilmente, para cada grupo excluído socialmente, há uma justificativa para tal empreendimento.

Para o pobre, a justificativa consiste em que, segundo os diversos extremistas, ele ou ela se mostra como vagabundo e preguiçoso que não quer trabalhar e faz filhos para conseguir subsídio do Governo. Assim, pobreza não tem a ver com má distribuição de renda, mas é devido a uma questão de caráter e opção de vida. Não dificilmente, se ouve os discursos hipócritas do tipo: "eu nasci pobre, mas batalhei e conseguir vencer na vida", ou ainda, os que dizem: "tá vendo, ela leu livros do lixo e conseguiu se formar em medicina". Esses tipos de discurso, além de serem desonestos intelectualmente, somente tentam justificar a postura anterior, desconsiderando os aspectos basilares como estrutura familiar, oportunidades na vida, educação, dentre outros. Tomar somente casos isolados para, por meio deles, tentar fazer uma regra geral se mostra desonesto em todas as suas formas, podendo até mesmo cair em certo discurso ideológico de uma "representação ilusória que fazemos do real" (BOCK; 2007, p.24)

Para o caso indígena, se considera um absurdo que eles vivam fora da sociedade e não se "adequem" ao modo de vida do Ocidente europeu. A suposição enganosa de que aquilo que é da cultura ocidental tem mais valor que o que não o é, dessa forma, justifica o extermínio. De igual modo, os donos do agronegócio no país, a fim de expandir seu latifúndios para a criação de gado e plantações que deterioram o solo, consideram um absurdo que grandes áreas sejam consideradas reservas indígenas.

Nesse cenário, para que haja maior produção e, consequentemente, maiores lucros para os bancos e latifundiários, as áreas indígenas começam a ser remarcadas, índios são tirados dos seus lugares de origem e diversos genocídios acontecem nas fazendas espalhadas pelos rincões do país. Dessa forma, o que se percebe é novamente o mesmo cenário de quando os europeus chegaram e dizimaram tribos inteiras que se encontravam nessas terras antes deles. Mais uma vez, só que agora em nome da religião do capital, se extermina aquele que é mais fraco e não se enquadra na proposta vigente. 
Para a comunidade LGBTTT, a justificativa para sua exclusão e extermínio se encontra em nome de falsa moral que se diz cristã. Em nome da defesa da família tradicional, dos bons costumes, do comportamento “aceitável” pela sociedade, verdadeiros grupos de extermínio se espalham pelo país, pregando tanto o ódio à comunidade LGBTTT, quanto, disfarçado de cristianismo, certa "cura" daquilo que consideram uma patologia.

O movimento evangélico, principalmente os pentecostais e neopentecostais são os que encabeçam a lista dos algozes dos movimentos LGBTTT, com seus discursos que se baseiam em, diversas vezes, leituras descontextualizadas dos textos bíblicos. Não é difícil ouvir discursos que incitam a não aceitação e a discriminação desse grupo em diversos púlpitos espalhados pelo país. Aliado a isso, a própria linguagem cotidiana reforça o preconceito, uma vez que ao se chamar alguém de "viado", "bicha", "gay etc., se consolida na cultura uma visão excludente e discriminatória desse grupo em relação ao meio em que vivem.

Para os negros e negras do país, a situação também não se mostra tão diferente assim e, em alguns pontos, se mostra ainda pior. Por muitas vezes ser um preconceito velado, esse tem a característica de se esconder atrás de certa "ordem" social. O negro é constantemente discriminado por sua cor e isso vai desde a uma entrevista de emprego até ser confundido, comumente, como ladrão nas ruas de nossas cidades. Diante dessa visão, a inferiorização do negro e da negra em nosso país é constante.

No campo religioso, o crescimento da intolerância e dos extremismos se mostra como preocupante. $\mathrm{O}$ fundamentalismo islâmico e cristão tem crescido fortemente: o primeiro no Oriente Médio, o segundo, nos países do Ocidente.

Não é difícil perceber que a revolta islâmica tem como uma das causas principais as diversas guerras promovidas pelas economias do Ocidente que, nos últimos anos, em nome de um capitalismo neoliberal e predador, promoveu guerras e financiou grupos, muitas vezes terroristas, para derrubadas de governo em diversos países do Oriente Médio. Isso gera a morte de diversos civis espalhados nos países atacados, tais como Iraque e Síria. Todo esse extermínio gera um contra-ataque por parte do fundamentalismo islâmico que, por sua vez, tornam as principais cidades do Ocidente alvos de atentados terroristas que matam outras centenas de civis inocentes. A isso, se responde com mais genocídios e o círculo segue ad infinitum. 
Em todos esses casos, dentre vários outros que poderiam ser citados, acontece aquilo que podemos chamar de desumanização. As minorias são, constantemente, desumanizadas e sofrem as consequências dessa desumanização em seu dia a dia. Quando há essa desumanização, já não importa o que é feito ao que foi desumanizado. Já não há dignidade nenhuma e se pode fazer o que quiser fazer, como mostra Hannah Arendt em seu livro Eichman em Jerusalém: um relato sobre a banalidade do mal. Dessa forma, as torturas, prisões e matanças são vistas como normais e até mesmo necessárias para que se tenha novamente uma sociedade "direita" e uma sociedade que "agrade" à vontade de Deus.

Assim, ao se tentar falar do campo religioso no cenário atual, é preciso levar em conta esses diversos fatores. Algo que de imediato nos chama a atenção é que, em todos esses casos, além da categoria da desumanização, se percebe a ausência da empatia. Não há empatia com aquele que pensa diferente. Na visão de grande parte de nossa sociedade atual que, sem dúvida, tem o maior acesso a informação da história da humanidade, ouvir o que pensa diferente ainda se mostra como tarefa extremamente difícil de se encontrar e, em muitos casos, como verdadeiro desafio.

A fim de falar do campo religioso atual, dentre as diversas abordagens possíveis, considerar-se-á dois temas: o diálogo ecumênico e o diálogo interreligioso.

\section{O que é um diálogo?}

A primeira pergunta que se deve fazer, antes de abordar qualquer tema a respeito do diálogo ecumênico e inter-religioso é se perguntar a respeito da categoria do diálogo. Embora se pareça algo que o próprio senso comum dá conta, na vida diária é possível se perceber que, muitas vezes, os conceitos mais fáceis são aqueles mais difíceis de se colocar em prática.

O dicionário Houaiss define o diálogo como "trocar (interlocutores) opiniões, comentários etc., com alternância dos papéis de falante e ouvinte; conversar" e também como "procurar entender-se [com outra(s) pessoa(s) ou outro(s) grupo(s)]”. Essa definição, por si só já esclarece alguns pontos sobre os quais é necessária certa atenção (HOUAISS, 2001, p.1031).

Em primeiro lugar, trata-se de uma troca de opiniões. Por mais simples que possa parecer, é importante observar que, para que se haja esse troca de opiniões é necessária a presença tanto de um outro, como também das opiniões diferentes a serem trocadas. Do contrário, não faz sentido se fazer 
trocas de opiniões quando as duas são iguais, uma vez que, se dois falam a mesma coisa, um deles está sobrando (Cf. MOLTMANN, 2004, p. 29).

Diante disso, a presença de um outro que pensa diferente se mostra como tarefa imprescindível para que haja algum tipo de diálogo. O outro, aquele que se coloca como o que vem de fora, é condição sine qua non nesse processo. Não há como, por definição, dialogar com o que pensa igual, somente com o que pensa diferente. Com o que pensa igual sobre determinado tópico, então, pode se haver compartilhamento, mas não diálogo.

Um segundo ponto que chama a atenção é que o diálogo é um procurar entender-se com outras pessoas e grupos. Nisso reside o uso daquilo que chamamos mais acima de empatia. A busca do entendimento a respeito da posição do outro implica em atentar para o que outro tem a dizer sobre determinado assunto, na tentativa de compreender seus pontos de partidas, caminhos e chegada.

Disso, é possível dizer que para que o diálogo seja efetivado, a disposição para a escuta é tarefa salutar. Não há como dialogar quando se há somente uma fala e não é possível fazer uma troca séria sem ouvir e atentar naquilo que se está trocando, seja uma mercadoria, seja opiniões sobre o assunto.

Diálogo e empatia, dessa forma, são tarefas que se entrecruzam. Não há diálogo sem empatia para como aquele ou aquela com quem dialogo. Assim, o diálogo se mostra como desafio duplo: ao mesmo tempo em que é um convite para o acolhimento do diferente em sua diferenciabilidade, também o é ao nos desafiar a ouvir profundamente o outro naquilo que ele tem a nos dizer de sua realidade e visão de mundo. Não tem como tentar fazer um diálogo ecumênico ou um diálogo inter-religioso sem ter consciência daquilo que se espera de um diálogo.

Com isso em mente, parece-nos claro que dialogar não tem a ver com o convencimento. A partir do momento em que há o convencimento do outro, encerra-se o diálogo; passa-se a ser uma partilha ou algum tipo de ensinamento a respeito do tópico que, anteriormente, estava em questão.

\section{O diálogo ecumênico}

Como vimos, o diálogo pressupõe a presença de opiniões divergentes a respeito de determinada temática. Agora, o que se quer dizer quando se fala em diálogo ecumênico? Ecumenismo vem da palavra grega oikouméne, que quer dizer a "terra inteira habitada". Assim, de início, essa palavra foi 
utilizada para descrever os esforços para promover a harmonia entre os representantes das diversas religiões e povos (Cf. HENN, 2003, p. 291-293).

Desde o Concílio de Cosntatinopla em 381 a palavra ecumênico é usada para significar "o conjunto de doutrinas e práticas aceitas por toda a Igreja (SANCHES, 2005, p.81)". Com o passar do tempo, e devido aos diversos embates ocorridos entre protestantes e católicos, a palavra ecumenismo passou a ser usada para a tentativa de promover a harmonia entre as diversas denominações cristãs (Cf. WOLFF, 2002). Nesse sentido, a partir de agora, ao dizermos diálogo ecumênico temos em mente o diálogo entre protestantes, católicos e ortodoxos.

O período da Reforma, como se sabe, foi um período de grande embate entre Protestantes e Católicos. As noventa e cinco teses levantadas por Lutero para correção dos caminhos que a Igreja havia tomado não foram aceitas pelo Catolicismo da Idade Média que, na tentativa de firmar sua posição e condenar as teses dos Reformadores, estabelece o Concílio de Trento.

O período inicial da Reforma tem, assim, momentos conturbados e que influenciou grandemente a forma como os protestantes passaram a ser vistos por diversos católicos no Brasil (Cf. Ibid.).

Ao longo da história dos embates entre Protestantes e Católicos em solo brasileiro, Wolff mostra que a imagem que uma igreja tem da outra tem base em questões históricas, possuindo assim, três momentos bem marcantes, a saber, a controvérsia apologética em que constam as diversas calúnias que uma igreja fazia da outra, na tentativa de "corrigir" os diversos erros nos quais a outra igreja estava; o respeito crítico onde se começa a ter um espírito de tolerância entre as igrejas; a convivência em que se percebe um espírito dialogal e de cooperação em diversas questões de ordem social (Cf. Ibid., p. 34-38).

Para Henn, o movimento ecumênico contemporâneo se inicia em Edimburgo, na Escócia, com a Conferência Missionária Mundial, em 1910, sendo fruto da intensificação da atividade missionária protestante na África, Ásia e Oceania. Assim, “a experiência de levar consigo suas divisões aos povos que intentavam apresentar a Cristo levou esses missionários a compreender de forma viva o escândalo da divisão cristã e o modo em que esta é um obstáculo para a missão da Igreja” (HENN, 2003, p.291).

Esse sentimento não foi sentido somente por Protestantes, mas como bem aponta Wolff, por cristãos de um modo geral. 
A consciência dos obstáculos para a vivência da fé desperta as confissões cristãs para a superação de toda diversidade que seja sinônimo de divisão, de modo que as consequências negativas do pluralismo eclesial justificam todo empenho pela restauração da unidade. A história dos esforços pela unidade é o resultado da percepção sobre quanto a divisão dos cristãos impede o testemunho do Evangelho (WOLFF, 2002, p. 76).

Essa conferência, por sua vez, deu origem à fundação do Conselho Missionário Mundial e, posteriormente, o Conselho Ecumênico das Igrejas, em 1948, da qual a Igreja Ortodoxa também faz parte (Cf. HENN, 2003, p.292; SANCHEZ, 2005, p.86).

Foi em 1962, no Concílio Vaticano II, que a posição católica a respeito do Ecumenismo se tornou mais clara. Mesmo que a preocupação com a unidade cristã possa ser percebida no documento de convocação Humanae salutis, de João XXIII:

No instante, pois, de generosos e crescentes esforços que de várias partes são feitos com o fim de reconstituir aquela unidade visível de todos os cristãos e que corresponda aos desejos do divino Redentor, é muito natural que o próximo concílio ilustre mais abundantemente aqueles capítulos de doutrina, mostre aqueles exemplos de caridade fraterna que tornarão ainda mais vivo nos irmãos separados o desejo de auspicioso retorno à unidade e lhes prepararão o caminho para consegui-la. (Humanae Salutis, n.8)

Texto mais importante para a questão ecumênica, propriamente dita se encontra no documento Unitatis redintegratio. Nesse documento, como bem aponta Sanchez, se encontra tantos os avanços da posição católica acerca do ecumenismo, mas também deixa bem claras as ambiguidades de sua posição (SANCHEZ, 2005, p.89).

Ao mesmo tempo em que reconhece que o Movimento Ecumênico, nascido em meio Protestante, é uma obra do Espírito que visa restaurar a unidade dos cristãos, recebendo-o com alegria e propondo que os católicos participem desse movimento, também reforça a doutrina de que a unidade dos cristãos é percebida na estrutura eclesiológica e, dessa maneira, todos aqueles que não estão sob a direção do Papa, não estão em verdadeira comunhão com a Igreja de Cristo que é de estrutura episcopal (Unitatis Redindegratio, n. 1- 4; SANCHEZ, 2005, p. 90-91).

Esse tipo de postura por parte da Igreja Católica gera grandes dificuldades para o diálogo ecumênico na atualidade, uma vez que, ancorada 
na ideia de que nela e, somente nela, é possível alcançar a plenitude dos meios de salvação:

Contudo, os irmãos separados, quer os indivíduos quer as suas Comunidades e Igrejas, não gozam daquela unidade que Jesus quis prodigalizar a todos os que regenerou e convivificou num só corpo e numa vida nova e que a Sagrada Escritura e a venerável Tradição da Igreja professam. Porque só pela Igreja católica de Cristo, que é o meio geral de salvação, pode ser atingida toda a plenitude dos meios salutares. Cremos também que o Senhor confiou todos os bens da nova Aliança ao único colégio apostólico, a cuja testa está Pedro, com o fim de constituir na terra um só corpo de Cristo. É necessário que a ele se incorporem plenamente todos os que de alguma forma pertencem ao Povo de Deus. Este Povo, durante a peregrinação terrena, ainda que sujeito ao pecado nos seus membros, cresce incessantemente em Cristo. É conduzido suavemente por Deus, segundo os Seus misteriosos desígnios, até que chegue, alegre, à total plenitude da glória eterna na celeste Jerusalém (Unitatis Redindegratio, n. 3,5).

Essa postura será a mesma com relação ao diálogo inter-religioso, conforme consta no documento Nostra Aetete, do mesmo Concílio.

O artigo de Thomas Rausch (2017, p. 87-100) levanta novas perspectivas e dificuldades dentro da temática do diálogo ecumênico. Rausch mostra que enquanto alguns consideram que esse diálogo passa por um chamado "inverno ecumênico", outros se mostram mais otimistas enquanto falam de um novo paradigma que segue desde 1988 e visa mais a unidade no comprometimento com a justiça, paz e integridade da criação, ou seja, uma comunhão de valores, mas do que uma unidade visível.

Da mesma forma, no que concerne às dificuldades, a questão litúrgica e sacramental ainda se coloca como um tema complicado na relação Católicos e Protestantes, bem como o crescimento dos movimentos neopentecostais, principalmente na América Latina e o surgimento das igrejas independentes na África e na Ásia (Cf. Ibid., p. 92).

Assim, para que se possa mover em frente na questão ecumênica, Rausch propõe quatro sugestões: a) um ecumenismo receptivo que se preocupa com aquilo que pode aprender com os outros mais do que aquilo que podem ensinar a eles; b) mesmo reconhecendo e incentivando um ecumenismo que tenha valores compartilhados, não se deve esquecer de também buscar uma unidade visível do Cristianismo; c) é necessário se preocupar com a formação de novos ecumenistas, a fim de que uma nova 
geração que pense essa questão possa se formar; d) mover-se em direção a uma hospitalidade eucarística, uma vez que essa tem caráter mais pessoal, enquanto a intercomunhão tem caráter mais formal; e) a busca para que se dissolva antigas divisões históricas, a fim de que haja amizades entre as igrejas, uma vez que "ecumenismo sempre começa com amizade" (Ibid., p. 96).

\section{A pluralidade religiosa}

O pluralismo religioso não é algo novo para a tradição cristã e judaica. O povo de Israel, em seu caminho de peregrinação, conviveu constantemente com inúmeros povos com outros deuses e outras práticas religiosas.

Em todo Antigo Testamento é possível perceber a convivência e a luta do povo de Israel com as outras "religiões" ao seu redor. Essa convivência, como nos mostra o texto bíblico, nem sempre se deu de forma amistosa, mas muito pelo contrário, se dava com diversos lutas e guerras entre os povos, tanto por questões territoriais, como também para mostrar quem era o Deus mais poderoso entre eles.

O caso de Elias e os profetas de Baal (1 Rs 18) deixa muito claro o último aspecto. No texto, a disputa de Elias com os profetas tem o intuito de mostrar quem era o Deus verdadeiro. Todo aquele, então, que não servia ao Deus verdadeiro, mas adorava outros deuses deveria, então morrer. Não coincidentemente, Elias, após ter sua oração atendida, leva os profetas de Baal ao ribeiro de Quisom, e ali os mata.

No período intertestamentário, também é grande o convívio do povo de Israel com outras religiões. É interessante lembrar que, durante um longo período, Israel esteve sob domínio de diversos impérios. Começando pelo império babilônico, passando pelo império persa, grego e romano, o povo judeu se viu constantemente sob a influência e, ao mesmo tempo, luta contra esses impérios que os dominavam na tentativa de manter sua crença no Deus de Abraão, Isaque e Jacó.

Ao mesmo tempo em que tentavam manter suas crenças, também recebiam influências na maneira de viver e na maneira de pensar sua própria sociedade, o que não é difícil de assumir, visto terem sido séculos em que se viveram sob domínio de outros povos, ou seja, mais de duas gerações, literalmente, nasceram, cresceram e morreram sendo dominados por Impérios com religiões diferentes das de seus antepassados.

O caso do império grego, que domina Israel de 333 a 165 a.C, pode ser tomado como exemplo da grande influência que essa cultura trouxe para o 
povo de Israel, se considerarmos a história relatada nos livros dos Macabeus. Esse livro, mesmo que não seja considerado canônico pelo Protestantismo, tem um valor histórico imenso e deve ser considerado para a compreensão da sociedade existente na época de Jesus de Nazaré.

Embora o império grego, com a morte de Alexandre o Grande, se divida entre os seus generais, ficando Selêuco com a parte em que residia o povo judeu nesse período, consideramos que esse período da história pode ser considerado dentro do império grego.

O livro conta a história da revolta de Judas Macabeu frente ao domínio de Selêuco e seus sucessores e a resistência de um grupo judeu frente aos valores trazidos pela cultura grega.

Ao mesmo tempo em que havia parte dos judeus que considerava válida a assimilação dos costumes gregos nas comunidades judaicas, havia também aqueles que resistiam a isso por considerarem algo que não era desejado por Deus. Do primeiro grupo, surge o grupo que no tempo de Jesus será conhecido como Saduceus, enquanto do outro, que segue Judas e sua família, surgirá aquele que será conhecido como os Fariseus. Vale aqui ressaltar a grande importância dos fariseus para que os costumes do povo judeu se mantivessem, bem como para a volta do monoteísmo judaico que, como sabemos, será basilar para a expectativa messiânica presente durante o primeiro século.

O Cristianismo, estabelecido após a morte e ressurreição de Jesus, também teve que conviver com as outras religiões que havia em seu redor. São constantes, nos primeiros séculos, as discussões apologéticas que visam mostrar o senhorio de Jesus Cristo e também a validade do discurso cristão em um momento de grande perseguição por parte do Império Romano que não aceitava que outra pessoa pudesse ser chamada de rei, no lugar de César.

Com isso, o Cristianismo, em sua origem, é conhecido dentro do Império Romano como sendo a seita do Nazareno, como nos mostra o relato do livro de Atos, em seu capítulo vinte e quatro. Com a conversão de Constantino em 312, gradativamente o Cristianismo vai alcançando espaços até, tempo depois, poder ser considerada a religião do Império, totalmente ligada ao poder político. As consequências disso, principalmente no que se refere ao pluralismo religioso se mostram avassaladoras.

A Idade Média, totalmente dominada por uma cristandade que detinha tanto o poder religioso como o poder político, é até hoje considerado como um período extremamente pouco tolerante com as outras religiões, bastando 
para isso lembrar as "caças às bruxas" do período inquisitório, bem como o movimento de Cruzadas, em sua luta contra os muçulmanos.

Nesse cenário de cristandade, a Igreja Católica se mostrava como a força balizadora de todo comportamento e de toda verdade no que se refere à crença cristã. Tudo aquilo que ia contra aquilo que a Igreja dizia deveria ser condenado como heresia e o castigo, como bem se sabe, no pior dos casos, era a fogueira. Nesse sentido, durante esse período, uma ideia de pluralismo religioso era inconcebível ao longo de toda Europa.

Com o movimento da Reforma, fruto também da influência Iluminista, as bases da própria sociedade começam a mudar. Não há somente uma forma de pensar e viver a fé cristã, como propunha o Catolicismo da Idade Média. Com a Reforma Protestante, um novo leque se abre. Ancorada sobre o princípio do sacerdócio de todos os crentes, o Protestantismo incentiva grandemente a livre interpretação do texto bíblico, que é revelado a todos e todas por obra do Espírito Santo. Da mesma forma, ancorada no princípio da Sola Fide, as obras de penitência, como entendida no Catolicismo, deixa também de ser a balizadora da vida cristã, importando muito mais a experiência de fé para a salvação.

A época de cristandade, que com o Iluminismo e o movimento de Reforma começa a ser escamoteada, terá seu fim com o advento da Modernidade. Essa, tendo o capitalismo como aliado, trará uma nova forma de ver a sociedade e, consequentemente, as religiões que se encontram nela.

A Modernidade, como bem nos mostra Sanchez, "está marcada pela descontinuidade histórica, pela transitoriedade", envolvendo um processo de intermináveis rupturas e fragmentações (SANCHES, 2005, p. 27). Contrariamente à rigidez da Idade Média, surge a fluidez da Modernidade, ou seja, uma época que é caracterizada por um processo simultâneo de criação e destruição constante, como bem aponto Sanchez.

A mudança, na Modernidade, passa a ser compreendida como um processo simultâneo de criação e destruição. Ao mesmo tempo que vão sendo implementados os alicerces da nova sociedade, vai sendo desencadeada a destruição da sociedade medieval. (...) Assim, para a Modernidade, a destruição criativa é inerente ao seu próprio mecanismo de funcionamento (Ibid., p. 28).

Uma das características da época Moderna é o uso instrumental da razão. A partir do advento desse novo período, a razão passa a ser vista como algo a ser usado para a transformação do mundo e da natureza. Essa, por sua 
vez, perde para a sociedade o caráter de divino. A natureza se faz presente esperando a transformação do sujeito sobre ela, com vistas ao progresso.

Da mesma forma, entra em cena a secularização. Sanchez nos dá uma boa definição acerca dessa palavra.

A secularização pode ser definida como o processo desencadeado pela Modernidade em que a religião perde o lugar de referência primordial para a compreensão do mundo. Do ponto de vista político-institucional, a Igreja católica romana perde o lugar de matriz religiosa e tem seu papel político diminuído. Com isso, abre-se a possibilidade para a separação Igreja-Estado, que vai marcar a vida política da sociedade (Ibid., p. 30).

A partir do momento em que a Igreja católica romana não é mais a balizadora de condutas e moral da sociedade, abre-se espaço, dentro de um mundo secularizado, à dimensão da escolha e responsabilidade do ser humano diante do mundo e do seu futuro. Assim, a Modernidade se mostra então com duas características: a primeira, o uso instrumental da razão, de maneira que o ser humano é aquilo que ele faz; a segunda é a questão da liberdade do homem de poder criar o que ele quiser criar (Cf. Ibid., p. 32).

Essas duas características ficam muito claras quando Touraine, em sua obra, diz que

A ideia de modernidade, na sua forma mais ambiciosa, foi a afirmação de que o homem é o que ele faz, e que, portanto, deve existir uma correspondência cada vez mais estreita entre a produção, tornada mais eficaz pela ciência, a tecnologia ou a administração, a organização da sociedade, regulada pela lei e a vida pessoal, animada pelo interesse, mas também pela vontade de se liberar de todas as opressões. Sobre o que repousa essa correspondência de uma cultura científica, de uma sociedade ordenada e de indivíduos livres, senão sobre o triunfo da razão? Somente ela estabelece uma correspondência entre a ação humana e a ordem do mundo, o que já buscavam pensadores religiosos, mas que foram paralisados pelo finalismo próprio às religiões monoteístas baseadas numa revelação. É a razão que anima a ciência e suas aplicações; é ela também que comanda a adaptação da vida social às necessidades individuais ou coletivas; é ela, finalmente, que substitui a arbitrariedade e a violência pelo Estado de direito e pelo mercado. A humanidade, agindo segundo suas leis, avança simultaneamente em direção à abundância, à liberdade e à felicidade (TOURAINE, 194, p. 9).

Tendo isso em mente, não é difícil entendermos porque o conceito marxista de homem se foca na questão do ser humano enquanto ser de 
cultura, onde cultura é considerada como sendo a alteração da natureza por parte do ser humano. Dentro do contexto da Revolução Industrial, não é de se admirar que, para nosso filósofo, o homem é realmente humano quando se realiza em seu trabalho e vê sentido nele. Assim, a alienação do ser humano é um problema grave, uma vez que, ao se alienar ao detentor do capital, esse deixa de ser aquele que transforma o mundo a partir da sua liberdade de criação, e passa a ser pago para o exercício de determinada função. Os pressupostos do uso da razão instrumental e da liberdade podem, assim, ser percebidos sem grandes esforços.

A secularização, por sua vez, que como mostramos, é aquela desloca a religião católica romana do seu centro, traz consigo também o deslocamento da religião da esfera social para a esfera do sujeito. Assim, a religião não tem mais, em um mundo secularizado, valor de referência absoluta para a vida social, passando a ser subordinada à consciência do sujeito (Cf. SANCHEZ, 2005, p. 35).

Moltmann também fará essa crítica com relação a essa nova característica trazida pela Modernidade. Em suas palavras:

Diferentes tradições religiosas perdem suas capacidade de ser o elemento de vínculo das sociedades e se tornam, ao invés disso, mera opções para consumidores religiosos a selecionar, para suas próprias razões privadas, razões não são para serem discutidas. Assim "democratizadas" religiões entra no mercado como objetos de escolhas subjetivas do mesmo modo que marcas de pasta de dente e sabão em pó: "Religião é agora um ítem de consumo para uma nação de "estou dando uma olhadinha (Window shoppers), diz Martin Marty (MOLTMANN, 1990, p.152).

Com todo esse cenário, é possível perceber que o advento e consolidação da Modernidade possibilita, e de alguma forma, até mesmo gera a questão do pluralismo religioso em sua forma atual.

Aqui, como bem aponto Sanchez, baseado no trabalho de Fortunato Malimaci, faz importante clarearmos a diferença entre pluralidade religiosa e pluralismo religioso. O primeiro tem a ver com a existência de diferentes grupos religiosos em uma sociedade com oportunidades de ação; o segundo, por sua vez, envolve as relações sociais entre estado, sociedade civil e atores religiosos, o que envolve questões jurídicas e simbólicas que permitem aos diversos grupos religiosos a possibilidade real de crescimento e expansão. Relações essas que, segundo Mallimaci, são constituídas historicamente (SANCHEZ, 2005, p. 38; MALLIMACI, 1996). 
Assim, fica claro que pluralidade religiosa nem sempre leva ao pluralismo religioso, uma vez que, para o segundo, são necessárias condições sociais que o possibilitem. Sancez resume bem a ideia quando diz que

Enquanto o conceito de pluralidade religiosa se refere à existência de diversas visões religiosas e à liberade de ação para as várias instituições e grupos religioss, o conceito de pluralismo religioso supõe o reconhecimento pela sociedade e pelo Estado das diversas instituições e grupos religiosos (SANCHEZ, 2005, p.39).

\section{O diálogo inter-religioso}

Partindo de que o Estado, com a chegada da Modernidade, se torna secularizado e não mais subordinado aos dogmas da época da cristandade, todas as religiões, então, tem o seu direito de existência garantido e deve ser respeitado. Aceitar essas diferenças como algo legítimo e com valor em si é posição fundamental para que seja possível o início do diálogo inter-religioso que, segundo Claude Geffré, exerce a "função de um novo paradigma teológico" (GEFFRÉ, 1989, p. 131) dentro do Cristianismo do século XX.

No Cristianismo, ficaram conhecidas três posições ao se falar de um diálogo inter-religioso. Em primeiro lugar, a posição exclusivista, que parte do pressuposto de que é somente no Cristianismo que se encontra a salvação e as outras religiões não passam de religiões enganosas que não atingem a verdade.

Tanto no Protestantismo quanto no Catolicismo há adeptos dessa corrente, somente mudando os pressupostos de como se dá essa salvação em cada uma das tradições: enquanto o Catolicismo se fundamenta na questão eclesiológica, ou seja, a salvação está tanto no conhecimento de Cristo como na pertença à Igreja Católica, no Protestantismo, isso se encontra na revelação exclusiva de Deus na pessoa de Jesus Cristo (SANCHEZ, 2005, p. 68-70).

A segunda posição é chamada de inclusivista. Nessa perspectiva, o centro está na pessoa de Jesus Cristo e não em uma questão eclesiológica, sendo a postura assumida, no Catolicismo, no Concílio Vaticano II. O que vale a pena termos em mente é que, na posição inclusivista, quem salva é Jesus Cristo. Esta salvação também se manifesta nas outras religiões, mas é sempre a salvação quem vem de Cristo. Dessa forma, as outras religiões se tornam ilegítimas em si mesmas, uma vez que a salvação promulgada por elas é sempre derivada d ação de Jesus Cristo (Cf. Ibid., p. 71-72).

$\mathrm{Na}$ posição da Igreja católica, como mencionamos mais acima, no documento do Vaticano II, Nostra Aetete e também em outros documentos 
elaborados pelo Concílio, mantém a ideia de que nas outras religiões há raios de verdade que ilumina a todo homem (cf. NA 2), o que também é mostrado no documento emitida pela Comissão Teológica Internacional que menciona outras ideias trazidas pelos textos conciliares:

Alguns textos do Vaticano II tratam especificamente das religiões não-cristãs: os que ainda não receberam o evangelho estão ordenados de diversos modos ao povo de Deus, e a pertença às diversas religiões não parece indiferente ao efeitos dessa "ordenação" (cf. LG 16). Reconhece-se que nas diversas religiões existem raios de verdade que ilumina toda homem (cf. NA 2), sementes do Verbo (cf. AG 11); pela disposição de Deus há nelas coisas boas e verdadeiras (cf. OT 16); encontram-se elementos de verdade, de graça e de bem não somente nos corações dos homens, mas também nos ritos e nos costumes dos povos, não obstante tudo deva ser "sanado, elevado e completado" (AG 9; LG 17) (COMISSÃO INTERNACIONAL TEOLÓGICA, 1997, p.46).

Podemos perceber, a posição do Catolicismo Romano se insere dentro de uma linha inclusivista. Contudo, não seria essa postura inclusivista somente outra forma de imperialismo?

A terceira posição é a pluralista. Nessa, a questão da mediação única de Jesus Cristo não é considerada como verdadeira, havendo então muitos caminhos de salvação, bem como diversos "salvadores" que podem levar a Deus. Uma das características da visão pluralista é seu enfoque teocêntrico e não mais cristocêntrico, o que permite abrir espaço para novas possibilidades de diálogo inter-religioso (Cf. Ibid., p. 73-74).

Contudo, como bem aponta Jürgen Moltmann, uma teologia do diálogo inter-religioso pluralista traz em si uma ideia imperialista, na medida que tenta definir um fundamento válido e comum para todo o diálogo. Nesse sentido, a nosso ver, a tentativa de superar uma postura imperialista claramente presente na postura exclusivista, não é efetivada, mas somente é mantida com outro discurso.

Uma teologia pluralista das religiões não pode ser menos imperialista que as teologias cristãs das religiões que Knitter quer superar. A natureza verbal do processo de "diálogo", por exemplo, já dá às chamadas "religiões do livro" uma vantagem importante. Uma teoria relativista da religião pode ser necessária para os Estados Unidos, dada sua diversidade. Até onde o pluralismo americano é um modelo situável da relação que deveria haver entre as religiões mundiais deve ser motivo de debate mais do que assumido como verdadeiro (MOLTMANN, 1990, p. 152). 
Diante desse cenário, não é difícil percebermos porque as primeiras tentativas de diálogo inter-religioso se deu pelo viés cristológico. A pessoa de Jesus sempre foi uma questão complicada para o Cristianismo. Desde os primeiros séculos, os cristãos se viram desafiados a responder aos diversos questionamentos que surgiam a respeito dessa temática.

Lembremos de duas questões: a questão de Ário, que motivou a resposta no Concílio de Niceia, de 325 e a questão da pesquisa a respeito do Jesus histórico e o Cristo da fé que segue até dias atuais.

Ário, que era bipo da Igreja em Alexnadria, acreditava que Jesus era a maior criatura de Deus, mas não era igual a Deus, o que, sem dúvidas, trazia grandes problemas para a soteriologia cristã, uma vez que, se Jesus não fosse Deus, de maneira nenhuma poderia salvar a humanidade, visto somente Deus ser poderoso para isso.

Da mesma forma, se Jesus não fosse Deus, então a humanidade não havia sido totalmente assumida pelo próprio Deus, impedindo assim a salvação humana, uma vez que somente aquilo que é assumido que pode ser salvo. Assim, a consequência da tese ariana é que a humanidade não estava salva em Jesus Cristo. Essa questão foi resolvida oficialmente no Concílio de Niceia, em 325, em que se estabelece a consubstancialidade de Jesus com Deus.

Outro exemplo é a questão da relação entre o Jesus histórico e o Cristo da fé que surge no século XVIII com Reimarus se segue até nossos dias. A questão gira em torno da tentativa de recuperar a verdadeira história de Jesus de Nazaré e nasce a partir do questionamento aos discursos oficiais da Igreja que, para alguns teólogos, não condiziam com aquilo que os Evangelhos falavam a respeito de Jesus.

Essas buscas a respeito do Jesus histórico, que se dividem em três fases até hoje, tem seus momentos bem definidos. A chamada primeira busca, ou Old Quest, compreende o período de 1748 a 1901 e tem como lema que o que é verdadeiro pode ser comprovado pelo viés histórico. Esse período chega ao fim com o trabalho de Albert Schweitzer que mostra que o Jesus histórico procurado pela Old Quest era impossível de ser encontrado.

A segunda fase, que se inicia em meados do século XX, tem seu enfoque em responder à proposta existencial trazida por Rudolf Bultmann. Para Bultmann, o que era importante não era o Jesus histórico, mas sim o Cristo da fé, ou seja a mensagem que foi deixada pelos seus discípulos, ou seja, o Kerigma. 
Ernst Käsemann, aluno de Bultmann, foi o responsável por iniciar esse novo período de busca do Jesus histórico. Käsemann, ao mesmo tempo que aceitava o resultado da primeira busca de que seria impossível encontrar uma biografia de Jesus, também acreditava que o relato era condição para manter firme a experiência de fé dos primeiros discípulos. Em suas palavras,

a historia não se faz historicamente importante pela tradição como tal, senão pela interpretação; a mera constatação de uns atos não basta, senão que se necessita a compreensão dos acontecimentos do passado, que se fizeram objetivos e se permaneceram fixados nos atos. A variação do kerigma neotestamentário prova que a cristandade primitiva manteve a confissão de sua fé através das mudanças de épocas e situações, ainda quando aquelas transformações a obrigaram a uma modificação da tradição que havia recebido. Ter somente consciência da história (Historie) que vamos arrastando detrás de nós não dá a esta, enquanto tal, nenhuma significação histórica, mesmo que seja completa de maravilhas e milagres (...) A história (Geschichte) não possui uma significação histórica mais do que na medida em que, por suas questões e suas respostas, fala em nosso tempo presente, encontrando por tanto uns intérpretes que entendam essa questões e essas respostas para nosso tempo e as apresentem (KASEMANN, 1978, p. 164-165).

Nesse sentido, e juntamente com outros teólogos, tais como Fuchs, Bornkamm, Colzemann e Ebeling, tinha em mente que o Jesus histórico é importante para o Cristo da fé, de maneira que não pode existir um sem o outro, já havendo no Jesus histórico uma cristologia implícita.

A terceira busca, que se estende até hoje, se concentrará em tentar retornar Jesus ao ambiente de seu tempo, à Galileia do primeiro século, na tentativa de refazer sua história a partir do contexto social, antropológico e cultura. Nomes como Geza Vermès, Gerd Theissen, John Meier, John Dominic Crossan e James Dunn são alguns dos pesquisadores que se debruçam sobre esse tema na atualidade.

Somente esses dois exemplos servem para mostrar o quão espinhoso é o estudo cristológico e como essa temática sempre foi ponto de dúvidas, questionamentos e tentativas de esclarecimentos dentro da sociedade em que se vivia.

Com relação ao diálogo inter-religioso, foram diversas as tentativas da cristologia. Essas tentativas vão desde John Hick, teólogo protestante, que com a "metáfora do Deus encarnado", retoma a questão de Adolf von Hanarck de que o cristianismo nada mais foi do que uma helenização do 
judaísmo, passando por Paul Knitter, para quem Jesus era um salvador dentre os outros e o que importa são os atos de justiça que se são feitos pelos seres humanos, e também por Jacques Dupuis, para o qual há a separação entre Jesus e o Logos e, dessa forma, o Logos, continua a ação de Cristo na história, até chegar em Claude Geffré, para o qual Jesus é o universal concreto, que quer dizer que mesmo que Jesus tenha sido um acontecimento particular, ele possui um sentido universal (Cf. HURTADO, 2012).

Todas essas tentativas pelo viés cristológico, porém, coloca a questão do diálogo inter-religioso em um impasse (YONG, 2003), se quisermos usar a expressão de Amos Yong, teólogo malasiano. Esse impasse está, justamente, em que nenhuma das abordagens leva em conta as outras religiões em si mesmas e uma teologia das religiões, mas somente se preocupam com o aspecto soteriológico do diálogo inter-religioso. Nesse sentido, haveria mesmo uma tentativa de diálogo, ou somente o que há é o velho discurso homogeneizador tão recorrente na história da igreja cristã?

É no intuito de resolver esse impasse que Amos Yong propõe a abordagem pneumatológica do diálogo inter-religioso. Nessa abordagem, o teólogo malasiano tenta trazer para os dias atuais a metáfora das duas mãos do Pai de Santo Irineu.

Ancorado naquilo que chama de uma pneumatologia fundacional e naquilo que chama de imaginação pneumatológica, ou seja, que toda experiência humana é uma experiência do espírito e que a imaginação pneumatológica seria aquilo que faz a ponte entre o que percebemos e nossa cognição da experiência que tivemos, Yong propõe que todas as coisas são compostas por Logos e Pneuma, sendo o primeiro as formas concretas das coisas e o segundo "o complexo de hábitos, tendências, e determina aquela forma, guia, e em algum aspecto manifesta e, ou determina seu comportamento fenomenal ou concreto" (Ibid., p. 130). Assim, para Yong, uma corporação que tem seu prédio e seus valores pode ser considerado como composto por Logos e Pneuma.

Contudo, ao fazer isso, Yong faz a separação entre as economias de Jesus e do Espírito, o que causa grandes problemas dentro de uma doutrina trinitária. Nesse pensamento, o Espírito age de maneira separada de Cristo. Ironicamente, o intuito de Yong era trabalhar dentro da abordagem pneumatológica por, segundo ele, essa trazer em si fortemente um caráter trinitário. No entanto, ao colocar as "duas mãos do Pai", como que trabalhando de formas separadas no mundo, elimina totalmente uma visão trinitária da ação de Deus no mundo. 
Em uma segunda obra, porém, Yong reconhece o erro de sua primeira abordagem, e tenta centrar novamente sua proposta na pessoa de Jesus no que tange à salvação e em uma pneumatologia que não é desvencilhada da questão do Filho (Cf. YONG, 2005, p. 111) ${ }^{1}$.

É possível que a ênfase do pentecostalismo no Espírito possa leva a negligenciar a pessoa e o trabalho do Filho? Possivelmente, sim; necessariamente não. Apesar de que a cristologia do Logos possa proteger os teólogos contra essa negligencia, a cristologia do Espírito não é completa sem suas fontes (Ibid., p. 111).

Nesse segundo momento, seu pensamento se voltará para a questão do Pentecoste relatado em Atos 2. Para o teólogo, dentre os diversos milagres que esse evento traz, possibilitar o encontro de pessoas que jamais se encontrariam por si mesmas pode ser considerado o maior deles (Cf. YONG, 2003, p.196-197). Assim, o Espírito é aquele que conserva a diversidade das vozes divinas e, dessa forma, a abordagem pneumatológica é capaz de segurar a tensão entre as confissões cristãs e as outras religiões.

Diante disso, para nosso teólogo, o cristianismo tem três tarefas no mundo atual: a primeira é aprender a falar as diversas línguas: da ciência, outras religiões e vários pós-modernismos a fim de podermos entender os contextos atuais. Em segundo lugar, entender essas diversas linguagens profundamente de maneira que possamos dialogar com os articuladores delas e em terceiro, a necessidade de traduzir apropriadamente essas linguagens para os termos e categorias cristãs, da mesma forma que as categorias cristãs precisam ser traduzidas para as outras linguagens, para que tenha algum significado diante das questões propostas à teologia cristã (Cf. Ibid., p. 237).

Se, para Yong, o evangelho vem sempre dentro de uma cultura, então se faz necessário que uma teologia seja feita de maneira multidisciplinar, multi-perspectiva e multicultural, bem como os cristãos também precisam se mostrar abertos a ouvir as outras religiões e aprender com elas.

Se outros tem algo a dizer sobre Deus, não deveríamos nós ao menos ouvir tanto simpaticamente como criticamente? Ainda mais, não apenas estamos sendo formados; nosso conhecimento de Deus permanece finito nesse lado do eschaton. Finalmente, dada a infinitude de Deus, como pode isso ser exaustivamente transmitido em tempo e palavras finitas? (Ibid.. p. 240).

\footnotetext{
1 A correção acerca da separação entre a missão do Filho e Espírito se apresenta se encontra
} na nota 81 . 


\section{Considerações Finais}

Diante do cenário que se coloca diante do mundo atual, é tarefa teológica pensar a fé cristã dentro de uma perspectiva plural. O pluralismo religioso que, como visto, é uma característica e consequência da própria Modernidade, é uma realidade que exige que teólogos e teólogas de nosso tempo estejam dispostos a repensar a fé cristã, a fim de que ela possa ser dita e compreendida pela nossa sociedade.

Nesse contexto, dentro de uma perspectiva multicultural e multidisciplinar, dois temas se mostram de grande importância para a teologia: o diálogo ecumênico e o diálogo interreligioso. Como vimos, o diálogo ecumênico cresceu grandemente no meio cristão, principalmente no século XX, com diversas iniciativas tanto Protestantes, como Católicas e Ortodoxas, embora ainda há muito a ser feito nessa questão, a fim de que a comunhão entre cristãos possa ser vista de uma maneira mais efetiva.

Quanto ao diálogo interreligioso, novas abordagens tem sido feitas para se pensar a relação do Cristianismo com as outras religiões universais. Começando com uma perspectiva cristológica e passando por uma perspectiva de caráter pneumatológico, a teologia cristã tenta encontrar maneiras de tornar o diálogo inter-religioso mais efetivo e que também traga propostas efetivas para os diversos problemas atuais de nossa sociedade.

A capacidade de ouvir o outro se mostra como tarefa mais que necessária em nossos dias e somente com essa disposição é que qualquer diálogo poderá, de alguma forma, produzir frutos que gerem vida para o mundo em que vivemos.

\section{Referências}

ARENDT, Hannah. Eichmann em Jerusalém: um relato sobre a banalidade do mal. São Paulo. Companhia das Letras: 1999.

BOCK, Ana Mercês Bahia, GONÇALVES, Maria das Graças Marchina, FURTADO, Odair (orgs). Psicologia sócio-histórica: uma perspectiva crítica em psicologia. $3^{\mathrm{a}}$ ed. São Paulo. Cortez: 2007.

COMISSÃO INTERNACIONAL TEOLÓGICA. O Cristianismo e as Religiões. São Paulo. Loyola: 1997.

Deustch Welle de 18/07/2016. Disponível em https://www.dw.com/pt-br/quem-\%C3\%A9o-eleitor-de-donald-trump/a-19407424. Acesso em: 22/04/2019. 
Dicionário Houaiss da língua portuguesa. 1 ed. Rio de Janeiro. Objetiva: 2001.

GEFFRÉ, Claude. Como fazer teologia hoje. São Paulo. Paulinas: 1989.

HENN, W.. Ecumenismo. In: Dicionario enciclopédico teológico, 4 ed. Navarra. Verbo Divino: 2003.

DocVatII, Humanae Salutis.

HURTADO, Manuel. A Encarnação: debate cristológico na teologia cristã das religiões. São Paulo: Paulinas, 2012.

Jornal Estadão de 18/10/2015. Disponível em: http://internacional.estadao.com.br/noticias/ geral,propondo-controle-de-estrangeiros--extrema-direita-vence-eleicoes-na-suica-,1781855. Acesso em: 03 mai. 2017.

KÄSEMANN, Ernst. Ensayos Exegéticos. Salamanca. Sígueme: 1978.

LEVY, Paulo Mansur. Carta de Conjuntura. n. 43. IPEA. $1^{\circ}$ trimestre de 2019.

MALLIMACI, Fortunato. Apuntes para uma comprensión de la pluralidade, diversidade y pluralismo em el campo religioso em el siglo XIX y XX. Guatelmala. Mimeo: 1996.

MOLTMANN, Jürgen. Experiências de reflexão teológica: caminhos e formas da teologia cristã. 2004.

Jürgen. Is "Pluralistic Theology" useful for the dialogue of world religions? In: D'COSTA, Gavin (ed). Christian Uniqueness reconsidered: the myth of a pluralistic theology of religions. Faith meet faith series. New York. Orbis: 1990, p. 152.

PNAD IBGE. Disponível em http://www.ibge.gov.br/home/estatistica/indicadores/ trabalhoerendimento/pnad_continua/. Acesso em 03 mai. 2017.

RAUSCH, Thomas. The presente state of ecumenism. In: Perspectiva Teológica, v. 49, n. 1, p. 87-100. Jan-Abr 2017.

SANCHEZ, Wagner Lopes. Pluralismo religioso: as religiões no mundo atual. São Paulo. Paulinas: 2005.

TOURAINE, Alain. Crítica da Modernidade. Petrópolis. Vozes: 1994.

DocVatII. Unitatis Redintegratio.

Site do UOL de 28/04/2017. Disponível em https://economia.uol.com.br/empregos-ecarreiras/noticias/redacao/2017/04/28/desemprego-e-de-137-e-atinge-142-milhoes-detrabalhadores-diz-ibge.htm. Acesso em 03 mai. 2017.

Wagner Lopes. Pluralismo religioso: as religiões no mundo atual. 2005.

WOLFF, Elias. Caminhos do ecumenismo no Brasil. São Paulo. Paulus: 2002.

YONG, Amos. Beyond the impasse: toward a pneumatological theology of religions. Minnesota. Baker Academic: 2003.

. Amos. The Spirit poured out on all flesh: pentecostalism and the possibility of

global theology. Michigan. Baker Academic: 2005.

Submetido em: 12-5-2017

Aceito em: 23-4-2019 